University of Nebraska - Lincoln

DigitalCommons@University of Nebraska - Lincoln

USDA Wildlife Services - Staff Publications

U.S. Department of Agriculture: Animal and Plant Health Inspection Service

2012

\title{
Impact of baiting on feral swine behavior in the presence of culling activities
}

Tyler A. Campbell

USDA/APHIS/WS National Wildlife Research Center, tcampbell@eastfoundation.net

David B. Long

National Wildlife Research Center, david.b.long@aphis.usda.gov

Michael J. Lavelle

USDA/APHIS/WS National Wildlife Research Center, michael.j.lavelle@aphis.usda.gov

Bruce R. Leland

United States Department of Agriculture, bruce.r.leland@aphis.usda.gov

Terry L. Blankenship

Welder Wildlife Foundation, tblankenship@welderwildlife.org

See next page for additional authors

Follow this and additional works at: https://digitalcommons.unl.edu/icwdm_usdanwrc

Part of the Life Sciences Commons

Campbell, Tyler A.; Long, David B.; Lavelle, Michael J.; Leland, Bruce R.; Blankenship, Terry L.; and VerCauteren, Kurt C., "Impact of baiting on feral swine behavior in the presence of culling activities" (2012). USDA Wildlife Services - Staff Publications. 1111.

https://digitalcommons.unl.edu/icwdm_usdanwrc/1111

This Article is brought to you for free and open access by the U.S. Department of Agriculture: Animal and Plant Health Inspection Service at DigitalCommons@University of Nebraska - Lincoln. It has been accepted for inclusion in USDA Wildlife Services - Staff Publications by an authorized administrator of DigitalCommons@University of Nebraska - Lincoln. 


\section{Authors}

Tyler A. Campbell, David B. Long, Michael J. Lavelle, Bruce R. Leland, Terry L. Blankenship, and Kurt C. VerCauteren 


\title{
Impact of baiting on feral swine behavior in the presence of culling activities
}

\author{
Tyler A. Campbell ${ }^{\mathrm{a}, *}$, David B. Long ${ }^{\mathrm{a}}$, Michael J. Lavelle ${ }^{\mathrm{b}}$, Bruce R. Leland ${ }^{\mathrm{c}}$, \\ Terry L. Blankenship ${ }^{\mathrm{d}}$, Kurt C. VerCauteren ${ }^{\mathrm{b}}$ \\ a United States Department of Agriculture, Animal and Plant Health Inspection Service, Wildlife Services, National Wildlife Research Center, \\ Florida Field Station, Gainesville, FL 32641, USA \\ ${ }^{\mathrm{b}}$ United States Department of Agriculture, Animal and Plant Health Inspection Service, Wildlife Services, National Wildlife Research Center, \\ Fort Collins, CO 80521, USA \\ c United States Department of Agriculture, Animal and Plant Health Inspection Service, Wildlife Services, San Antonio, TX 78249-3378, USA \\ d Welder Wildlife Foundation, Sinton, TX 78387, USA
}

\section{A R T I C L E I N F O}

\section{Article history:}

Received 12 October 2011

Received in revised form 5 January 2012

Accepted 9 January 2012

\section{Keywords:}

Baiting

Culling

Depopulation

Epidemic

Eradication

Feral swine

Sus scrofa

\begin{abstract}
A B S T R A C T
We studied the effects of baiting on feral swine (Sus scrofa) movements and corresponding likelihood of disease spread under real and simulated culling pressure. Our objectives were to determine the proportion of feral swine that used the bait station site, and if baiting of feral swine altered areas of utilization, distances from location centroids to treatment location (control or bait station), and movement rates by survivors during culling activities. We hypothesized that the bait station would increase the sedentary nature of feral swine, thus reducing the potential for dispersal and hence disease dispersal. Our experiment was conducted between February and May 2011 on the Rob and Bessie Welder Wildlife Foundation (WWF) in San Patricio County, Texas. We trapped 83 feral swine and placed GPS collars on 21 animals. We established and maintained a centralized bait station on one side of the WWF from 13 March to 27 April. We conducted population-wide culling activities, including trapping, controlled shooting, drive shooting, and aerial gunning, from 3 to 27 April and removed 143 feral swine ( 4.6 feral swine $/ \mathrm{km}^{2}$ ). Areas of utilization did not differ between treatments (control or bait station). However, we found location centroids of bait station site feral swine to be closer to the treatment location than those of control site animals and daily movement rates of bait station site feral swine to be $39 \%$ greater than movement rates of control site animals. Based on our observation that only $62 \%$ of feral swine trapped in proximity to the bait station used it, we cannot recommend baiting as an alternative to fences for containing animals during culling activities. However, there is value in using bait stations to describe patterns of feral swine movements, facilitate observation, and improve efficacy when conducting removals.
\end{abstract}

Published by Elsevier B.V.

\footnotetext{
* Corresponding author at: USDA-APHIS-Wildlife Services, National Wildlife Research Center, Florida Field Station, 2820 East University Avenue, Gainesville, FL 32641, USA. Tel.: +1 352375 2229; fax: +1 3523775559.

E-mail addresses: tyler.a.campbell@aphis.usda.gov (T.A. Campbell), david.b.long@aphis.usda.gov (D.B. Long), michael.j.lavelle@usda.aphis.gov (M.J. Lavelle), bruce.r.leland@aphis.usda.gov (B.R. Leland), tblankenship@welderwildlife.org (T.L. Blankenship), kurt.c.vercauteren@usda.aphis.gov (K.C. VerCauteren).
} 


\section{Introduction}

Feral swine (Sus scrofa) are an invasive pest species, have a variety of damaging impacts around the globe, and are becoming abundant across the United States (Ditchkoff and West, 2007). Negative impacts of feral swine include degradation of native vegetation and surface water (Cushman et al., 2004; Kaller and Kelso, 2006), predation on wildlife and livestock (Seward et al., 2004), and transmission of pathogens to humans and livestock (Atwill et al., 1997; Jay et al., 2007; Hall et al., 2008; Meng et al., 2009; Wyckoff et al., 2009). Some important livestock pathogens that feral swine are susceptible to include pseudorabies virus, Brucella suis, classical swine fever virus (CSF), foot-and-mouth disease (FMD), and Mycobacterium bovis (Williams and Barker, 2001).

Fencing has been proposed for containment of emergency disease epidemics in free-ranging feral swine (Lavelle et al., 2011); however pathogen containment will likely not occur with fences alone, because of their high construction costs, incomplete effectiveness, and because they are time consuming to erect (Reidy et al., 2008; Lavelle et al., 2011). For example, in Australia it has been demonstrated that several weeks could be expected to pass before passive surveillance detected an emergency epidemic in feral swine (Hone and Pech, 1990); during this time there could be substantial spread of pathogens and related disease.

Therefore, emergency disease epidemics involving feral swine will rely on culling a relatively high proportion of the population to reduce the number of contact events between animals, with culling efforts exceeding a population threshold (Ward et al., 2007, 2009, 2011). This, in turn, may lead to pathogen fadeout (Lloyd-Smith et al., 2005), as the number of secondary infections becomes less than required for infection persistence (Wobeser, 1994). Under this reasoning, epidemics can be contained within a zone of culling around an infected area of interest, because in that zone the population abundance will be too low for pathogens to spread, thus containing infection (Ward et al., 2007, 2009, 2011; Wobeser, 1994). Similar logic exists for wild boar management programs seeking to control emergency disease epidemics through vaccination (Rossi et al., 2010; Ballesteros et al., 2011).

In the United States, culling techniques for feral swine include recreational harvest, controlled shooting, aerial gunning, trapping, and snaring (Campbell and Long, 2009a). However, motivation for feral swine movement varies with different culling methods. For example, aerial gunning has been found to have minor impacts on the movements of surviving feral swine (Dexter, 1996; Campbell et al., 2010) and ground-based pursuits resulted in the highest probability of fence breaches relative to controlled shooting and aerial gunning in enclosed settings (Lavelle et al., 2011). Population reductions may be disruptive and could potentially trigger detrimental dispersal of infected animals (Sodeikat and Pohlmeyer, 2002). Also, feral swine may respond to human disturbance by altering their behavior to evade human activity, thus complicating disease management activities (Hanson and Karstad, 1959; Muir and McEwen, 2007).
Other complementary tools may need to be integrated with culling activities to minimize potential for dispersal and spread of disease. One such tool that needs evaluation is the use of strategically implemented bait stations to abate feral swine dispersal once culling activities begin. Bait stations have been used to trap feral swine (Matschke, 1962; Belden and Frankenberger, 1977; Williams et al., 2011b), remove feral swine during controlled shooting campaigns (McCann and Garcelon, 2008), deliver pharmaceuticals to feral swine, including toxicants (Cowled et al., 2006a,b; Campbell et al., 2011), monitor populations relative to control activities (Reidy et al., 2011), and divert feral swine away from seasonally available resources, such as vineyards (Calenge et al., 2004). However, more information is needed about the impacts of baiting on feral swine behavior, particularly in the presence of common population-wide culling activities such as trapping, controlled shooting, and aerial gunning to refine strategies and develop appropriate contingency plans that could be implemented in an emergency disease epidemic.

We studied the effects of baiting on feral swine movements and corresponding likelihood of disease spread under real and simulated culling pressure. Our objectives were to determine the proportion of feral swine that used the bait station site, and if baiting feral swine altered areas of utilization, distances from location centroids to treatment location (control or bait station), and movement rates by survivors during culling activities. We hypothesized that a large proportion of animals would use the bait station site, and that baiting would cause smaller areas of utilization, focus proximity more near bait, and decrease movement relative to culling activities. However, if our data suggested that few feral swine used the bait station site and that animals ranged widely and permanently moved outside former ranges during culling activities in the presence of baiting, then this practice would be an inappropriate tool for containing feral swine during disease management campaigns.

\section{Materials and methods}

\subsection{Study area}

Our experiment occurred from February to May 2011 on the Rob and Bessie Welder Wildlife Foundation (WWF) $\left(28^{\circ} 06^{\prime} \mathrm{N}, 97^{\circ} 22^{\prime} \mathrm{W}\right)$ in San Patricio County, Texas. The WWF is approximately $31 \mathrm{~km}^{2}$ and receives an average of $91 \mathrm{~cm}$ of rainfall annually. The WWF is located in the Tamualipan Biotic Province of Texas, and is transitional between the Gulf Coast Prairies and Marshes and the Rio Grande Plains vegetation areas (Fig. 1; WWF, 2009). The WWF is bordered on the north by the Aransas River, the west by United States Highway 77, and the south and east by private rangeland. Overstory vegetation consists of huisache (Acacia farnesiana), mesquite (Prosopis glandulosa), live oak (Quercus virginiana), cedar elm (Ulmus crassifolia), net leaf hackberry (Celtis reticulate), anaqua (Ehretia anacua) and muscadine (Vitis rotundifolia). Population density estimates from the WWF were 4.3-7.7 feral swine $/ \mathrm{km}^{2}$ (Reidy et al., 


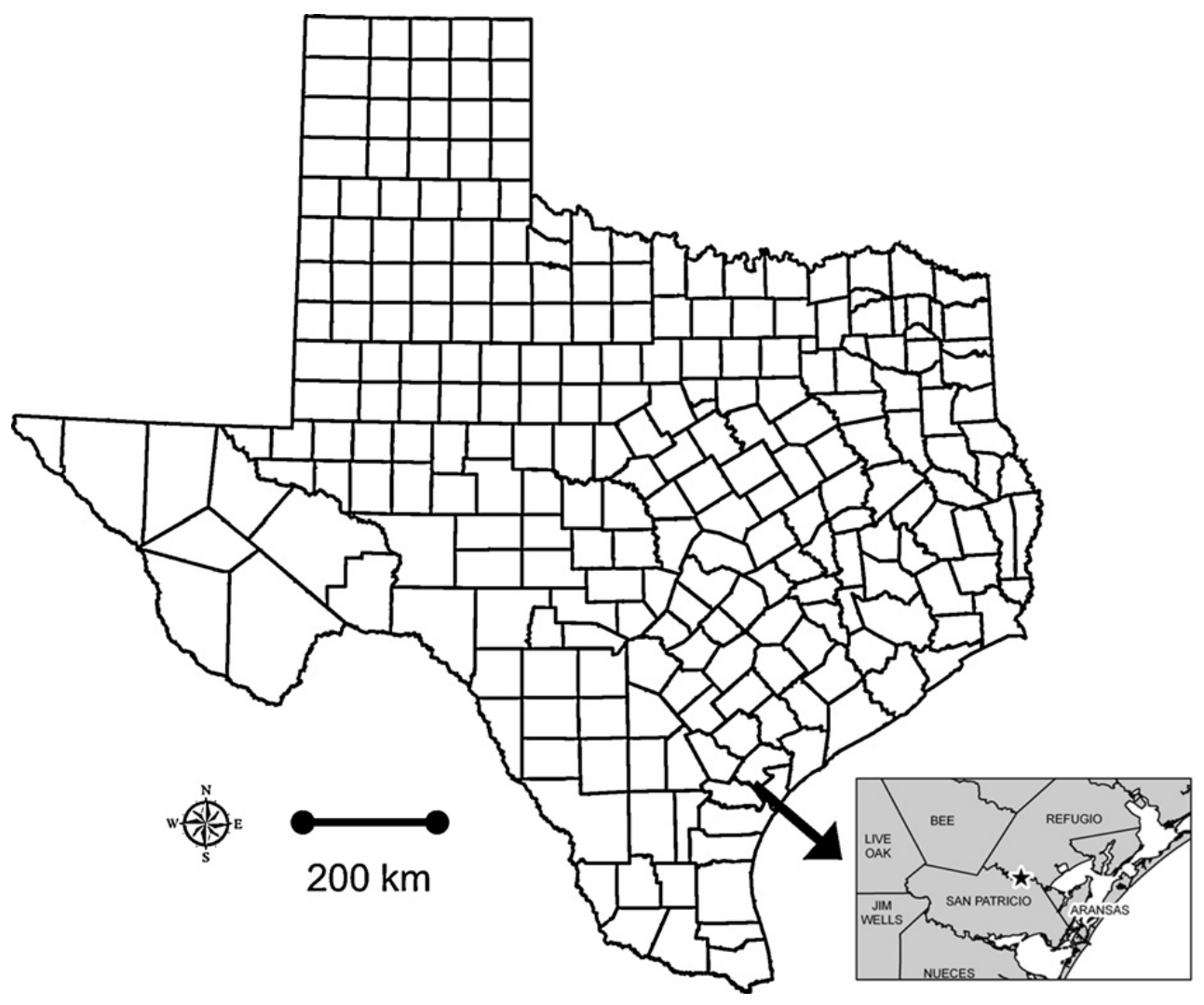

Fig. 1. Location of the Rob and Bessie Welder Wildlife Foundation in San Patricio County, Texas.

2011). Public access to the WWF was restricted during our experiment.

\subsection{Animal capture}

We trapped feral swine in February on the WWF using 16 rooter-door box traps $(2.5 \mathrm{~m} \times 1 \mathrm{~m} \times 1 \mathrm{~m})$ baited with whole kernel corn. Eight traps were placed on the east side of the property and 8 traps were placed on the west side of the property. Distance between east and west trapping site centroids was $8 \mathrm{~km}$. We immobilized and ear-tagged all feral swine captured and placed Global Positioning System (GPS) collars (GPS 3300S, Lotek Wireless Inc., Newmarket, ON, Canada) on animals estimated to be $\geq 82 \mathrm{~kg}$. We used physical restraint for animals not receiving collars and chemical immobilization $(4.4 \mathrm{mg} / \mathrm{kg}$ body weight Telazol ${ }^{\circledR}$ [Fort Dodge Animal Health, Fort Dodge, IA, USA] plus $2.2 \mathrm{mg} / \mathrm{kg}$ body weight xylazine; Kreeger et al., 2002) for animals receiving collars. Following handling of chemically immobilized animals, we used an intramuscular injection of yohimbine hydrochloride $(0.15 \mathrm{mg} / \mathrm{kg}$ body weight; Kreeger et al., 2002) as a reversal agent. Our GPS collars continuously emitted a very high frequency (VHF) signal and were equipped with a 6-h mortality sensor. Capture and handling procedures were approved by the National Wildlife Research Center's Institutional Animal Care and Use Committee (QA-1826).

\subsection{Experimental bait station}

We randomly assigned bait station placement to either the east or west trapping site centroids with a flip of a coin. We established the bait station by placing $580 \mathrm{~kg}$ of whole kernel corn on the ground on 13 March and maintained the bait station through 27 April. We checked the bait station daily and recharged it with whole kernel corn as needed. We distributed approximately $3335 \mathrm{~kg}$ of bait at the station throughout the experiment. We monitored animal visitation at the west trapping site centroid (control site) and bait station (east trapping site centroid) with motion-sensing digital photography (Rapid-fire, Reconyx, Holmen, WI, USA). We determined mean daily visitation by feral swine and other mammals at each of the sites from digital images.

\subsection{Culling activities}

We conducted culling activities over 4 weeks from 3 to 27 April and each activity occurred over approximately one week with no temporal overlap. Culling activities were deployed at increasing levels of perceived motivation, such that trapping occurred first, followed by controlled shooting, drive shooting, and aerial gunning.

During the trapping phase, we used 4 rooter-door box traps $(2.5 \mathrm{~m} \times 1 \mathrm{~m} \times 1 \mathrm{~m})$ baited with whole kernel corn within $400 \mathrm{~m}$ of the control site and 4 within $400 \mathrm{~m}$ of the bait station site. We checked, re-baited, and set traps every morning, documenting and removing every feral swine captured. We used 20 trap nights at both the control site and bait station site and recorded the number of feral swine removed by site.

During the controlled shooting phase, we simultaneously used 2 sharpshooters at the control site and 2 sharpshooters at the bait station site during crepuscular 
and nocturnal hours. Controlled shooting activities occurred within $1 \mathrm{~km}$ of either the control site or bait station site. We used light capturing (Pinnacle-AN/PVS-7B, ITT Nightvision and Imaging Inc., Roanoke, VA, USA) and forward looking infrared (Palmir Digital Camera IR 250, Ratheon Company, Waltham, MA, USA) technologies to locate and identify animals by species. Once we identified feral swine, we either removed them with a gunshot from a scoped high-powered rifle or harassed them with bird loads fired from a 12-gauge shotgun, depending upon whether a lethal shot could be obtained. Our purpose with shots fired from shotguns was to simulate a removal attempt and no efforts to remove feral swine were made with this type of firearm. We recorded the number of hours spent, shots taken, and feral swine removed by site.

During the drive shooting phase, 2 personnel used homing techniques from 07:00 to $12: 00 \mathrm{~h}$ to locate individual collared feral swine with the aid of their unique VHF signal, a radio receiver (R2000, Advanced Telemetry Systems Inc., Isanti, MN, USA), and a 4-element Yagi antenna. Our purpose with this phase was to drive feral swine from cover and stimulate movement of collared individuals and members of their social group. Once we initiated movement, we pursued collared animals on foot and attempted to harass animals with bird loads fired from a 12-gauge shotgun. As in the controlled shooting phase, no efforts to remove feral swine were made with this type of firearm. We attempted to perform 1-2 drives on each collared animal and no more than one drive per collared feral swine occurred per day. We georeferenced our drives with the aid of a handheld GPS unit (GPSMAP 60, Garmin International Inc., Olathe, KS, USA). We uploaded drive paths into ArcView ${ }^{\circledR} 3.2$ (Esri, Redlands, CA, USA). We recorded whether collared feral swine were observed individually or in a group, shots taken, and length of drives.

During the final phase, we conducted aerial gunning operations by helicopter over 2 days. We attempted to remove all feral swine observed without collars and used collared animals to aid in locating others (Mcllroy and Gifford, 1997). We recorded flight time and path, and number of marked (ear-tagged) and unmarked feral swine removed. Our helicopter was equipped with a GPS unit, and we uploaded flight paths into ArcView. We reported the estimated minimum distance between individual feral swine and the helicopter during aerial gunning.

At the conclusion of our culling activities, we initiated a 4-week period in which no baiting or culling activities occurred at either site. During this period, no human activity related to the experiment occurred. Our purpose during this period was to determine feral swine movements after cessation of baiting.

\subsection{Animal movements}

We programmed collars to collect locations every $4 \mathrm{~h}$ from 13 February to 2 April and from 8 May to 31 May. Also, collars were programmed to collect locations every 15 min from 3 April to 7 May during our culling activities. We recovered collars by radio-controlled drop-off mechanisms in June and uploaded location data into ArcView.
We estimated areas of utilization of feral swine using locations collected before baiting (13 February to 12 March), during baiting (13 March to 2 April), and after baiting (8-31 May) by site (control or bait station). We used the fixed-kernel method (Worton, 1989) to generate 95\% utilization distributions (UD) and 50\% UD areas using the Animal Movement Extension of ArcView (Hooge and Eichenlaub, 1997). We used least square cross validation as the smoothing parameter on the kernel distributions (Silverman, 1986). We overlaid 95\% and 50\% UD polygons on coverage maps of the WWF using ArcView. Additionally, we calculated location centroids (arithmetic mean of Universal Transverse Mercator coordinates of locations) from feral swine locations collected before baiting, during baiting, during culling activities, and after baiting and report the mean distance from location centroids to treatment location (control or bait station site). Furthermore, we calculated a minimum convex polygon (MCP; Mohr, 1947) using ArcView from locations generated before and during baiting and determined if feral swine moved outside of this area in response to culling activities.

We determined movement rates from feral swine locations collected during culling activities (3-27 April). We used the Animal Movement Extension of ArcView to calculate the distance between sequential locations. We determined the mean distance moved per day, as a measure of activity, for each culling phase (trapping, controlled shooting, drive shooting, and aerial gunning) and for days in which no human activities occurred on the WWF.

\subsection{Statistical analyses}

We compared feral swine UD areas, distance from location centroids to treatment locations, and movement rates between sites and among periods with a mixed model analysis of repeated measures. For these models, we used individual swine as the repeated factor or subject, treatment site as the between-subjects factor, and period as the within-subject factor using SAS PROC MIXED (Littell et al., 2006). Additionally, for these models we selected appropriate covariant structures of either unstructured, compound symmetry, autoregressed with and without random subjects, or Toeplitz using information criteria (Littell et al., 2006). We report Kenward-Roger adjusted analysis of covariance statistics and if a significant main effect was detected, then we compared model adjusted means using the least square means (LSMEANS) procedure in SAS PROC MIXED. We determined statistical significance at $\alpha=0.05$.

\section{Results}

\subsection{Animal capture, locations, and bait station visitation}

We trapped 83 feral swine on the WWF and placed GPS collars on 10 animals in proximity to the control centroid and on 15 animals in proximity to the bait station. We uploaded 55,886 GPS locations from 21 recovered collars, which were successful in generating GPS locations on $84 \%$ of attempts. Prior to experimentation, one animal slipped its collar and one animal died. Additionally, we were unable 
Table 1

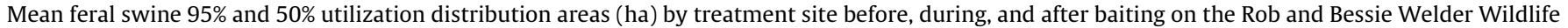
Foundation, Texas, February-May 2011.

\begin{tabular}{|c|c|c|c|c|c|c|c|}
\hline \multirow[t]{3}{*}{ Period } & \multirow{3}{*}{$\begin{array}{l}\text { Utilization } \\
\text { distribution }\end{array}$} & \multicolumn{6}{|c|}{ Treatment site } \\
\hline & & \multicolumn{3}{|c|}{ Control } & \multicolumn{3}{|c|}{ Bait station } \\
\hline & & $n$ & Mean & SE & $n$ & Mean & SE \\
\hline \multirow[t]{2}{*}{ Before baiting } & $95 \%$ & 13 & 141 & 36 & 8 & 263 & 86 \\
\hline & $50 \%$ & 13 & 16 & 4 & 8 & 26 & 8 \\
\hline \multirow[t]{2}{*}{ During baiting } & $95 \%$ & 12 & 103 & 35 & 8 & 87 & 14 \\
\hline & $50 \%$ & 12 & 11 & 3 & 8 & 12 & 3 \\
\hline \multirow[t]{2}{*}{ After baiting } & $95 \%$ & 9 & 65 & 17 & 5 & 177 & 63 \\
\hline & $50 \%$ & 9 & 10 & 3 & 5 & 26 & 14 \\
\hline
\end{tabular}

to locate and recover one collar and one collar malfunctioned.

Our analysis of location data indicated that 5 of 13 animals trapped in proximity to the bait station did not use the bait station. Mean (range) of distances from trap sites to the bait station for animals that used and did not use the bait stations were $624 \mathrm{~m} \mathrm{(238-1847)} \mathrm{and} 953 \mathrm{~m}$ (241-2134), respectively. Hereafter, we considered only animals that used the bait station as treatment animals (5 males and 3 females) and all others as control animals (9 males and 4 females).

At the control site we recorded 47 visits by white-tailed deer (Odocoileus virginianus), 26 visits by collared peccaries (Pecari tajacu), 16 visits by feral swine, and 4 visits by raccoons (Procyon lotor). At the bait station site we documented 2695 visits by feral swine, 96 visits by white-tailed deer, 17 visits by collared peccaries, and 5 visits by raccoons. Mean daily visitation at the bait station site peaked for feral swine from 3 to 9 April during week 4 of baiting (trapping phase) and for white-tailed deer from 17 to 23 April during week 6 of baiting (drive shooting phase; Fig. 2). Feral swine visitation to the bait station site dropped precipitously from 10 to 16 April during week 5 of baiting (controlled shooting phase) and from 24 to 30 April during week 7 of baiting (aerial gunning phase; Fig. 2).

\subsection{Culling activities}

During the trapping phase, we captured and removed one feral swine from the control site and 2 feral swine from the bait station site. All animals removed were marked previously with ear-tags from our original trapping effort. Also, the animal from the control site had previously slipped its collar and an animal from the bait station site was collared.

During the controlled shooting phase, we applied $53.7 \mathrm{~h}$ of effort to the control site and $54.8 \mathrm{~h}$ of effort to the bait station site. We fired 17 shots on the control site and 20 shots on the bait station site. We removed 7 feral swine from the control site and 7 feral swine from the bait station site. Two of the removed animals from the control site were marked and 3 animals from the bait station site were marked, including one with a collar.

We conducted 27 drives on 20 collared feral swine during the drive shooting phase; 2 drives were conducted on 7 feral swine. Mean (range) distance per drive was $457 \mathrm{~m}$ (12-1600). Mean (range) shots made per drive were 12
(2-31). Mean (range) group size observed per drive were 3 (1-10). We removed one collared feral swine from the control site during this phase due to safety concerns of personnel; this animal was removed from a distance of $1 \mathrm{~m}$.

During the aerial gunning phase, our helicopter flight time was $12.0 \mathrm{~h}$, during which we removed 125 feral swine (10.4 feral swine removed/h). We estimated there were 51 marked feral swine without collars alive during aerial gunning, of which 12 were shot from the helicopter (24\%). We determined the mean (range) minimum distance between collared feral swine and the helicopter during aerial gunning to be $22 \mathrm{~m}(1-65)$.

\subsection{Animal movements}

We found no interaction between sites and periods for the $95 \%$ and $50 \%$ UD areas. The 95\% UD areas did not differ between sites (Table $1 ; F_{1,19.1}=2.02, P=0.171$ ), but varied among periods $\left(F_{2,31.8}=5.00, P=0.013\right)$. Utilization distributions were greater before baiting than during and after baiting. Similarly, 50\% UD areas did not differ between sites $\left(F_{1,17.3}=0.74, P=0.400\right)$, but varied among periods $\left(F_{2,13.6}=4.20, P=0.038\right)$. These utilization distributions during baiting were less than before and after baiting. We found 7 of 8 feral swine in the bait station treatment to shift their 50\% UD to include the bait station site during baiting and that the 50\% UD did not include the bait station site or control site before or after baiting for any feral swine.

We found no interaction between sites and periods for the distance of feral swine location centroids to treatment location (control or bait station sites). Distance of feral swine location centroids to treatment location varied between sites (Table 2; $F_{1,18.6}=5.86, P=0.026$ ), but not among periods $\left(F_{3,47.5}=2.58, P=0.064\right)$. We found location centroids of bait station site feral swine to be closer than those of control site feral swine. Also, we observed that 10 of 21 feral swine moved outside their before baiting MCP and during baiting MCP, presumably in response to culling activities. Specifically, 4 animals moved a mean distance of $780 \mathrm{~m}$ for a mean duration of $86 \mathrm{~min}$ in response to trapping activities; 2 animals moved a mean distance of $988 \mathrm{~m}$ for a mean duration of $412 \mathrm{~min}$ in response to controlled shooting; 4 animals moved a mean distance of $1113 \mathrm{~m}$ for a mean duration of $544 \mathrm{~min}$ in response to drive shooting; and 2 animals moved a mean distance of $1700 \mathrm{~m}$ for a duration of 


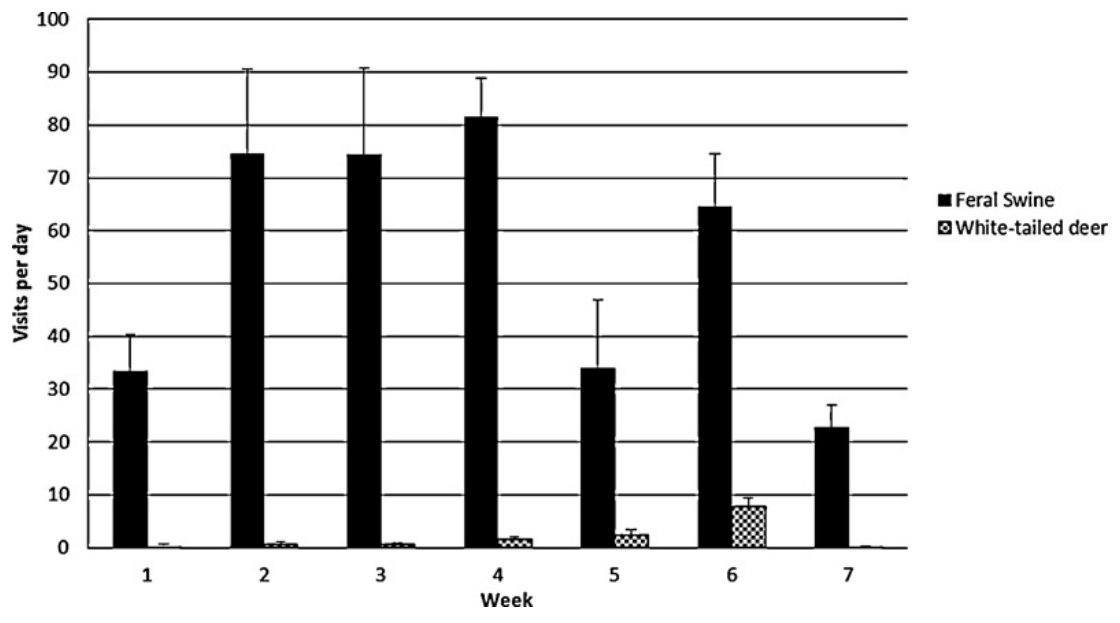

Fig. 2. Mean (SE) daily visitation by week at the bait station on the Rob and Bessie Welder Wildlife Foundation, Texas by feral swine (Sus scrofa) and white-tailed deer (Odocoileus virginianus), 13 March to 30 April 2011.

\section{Table 2}

Mean feral swine distance $(\mathrm{m})$ from location centroids to treatment location (control or bait station sites) by treatment site before baiting, during baiting, during culling activities, and after baiting on the Rob and Bessie Welder Wildlife Foundation, Texas, February-May 2011.

\begin{tabular}{|c|c|c|c|c|c|c|}
\hline \multirow[t]{3}{*}{ Period } & \multicolumn{6}{|c|}{ Treatment site } \\
\hline & \multicolumn{3}{|c|}{ Control } & \multicolumn{3}{|c|}{ Bait station } \\
\hline & $n$ & Mean & SE & $n$ & Mean & SE \\
\hline Before baiting & 13 & 1739 & 333 & 8 & 932 & 230 \\
\hline During baiting & 12 & 1896 & 290 & 8 & 491 & 80 \\
\hline During culling activities & 13 & 1745 & 316 & 7 & 606 & 93 \\
\hline After baiting & 9 & 2096 & 532 & 5 & 1067 & 204 \\
\hline
\end{tabular}

$240 \mathrm{~min}$ in response to aerial gunning. These movements outside of former ranges were conducted independently of treatment group, with 5 different control site animals and 5 different bait station site animals displaying movements.

We observed no interaction between sites and period for the mean distance moved per day. Distance of feral swine movements differed between sites (Table 3; $F_{1,16.7}=14.50, P=0.002$ ), but not among periods $\left(F_{4,62.1}=0.68, P=0.608\right)$. We found feral swine daily movement rates of bait station site feral swine to be approximately $1958 \mathrm{~m}$ (39\%) greater than movement rates of control site animals (Table 3 ).

\section{Table 3}

Mean feral swine daily distance moved (m) by treatment site during trapping, controlled shooting, drive shooting, and aerial gunning culling phases, and for days in which no human activities occurred on the Rob and Bessie Welder Wildlife Foundation, Texas, April 2011.

\begin{tabular}{|c|c|c|c|c|c|c|}
\hline \multirow[t]{3}{*}{ Period } & \multicolumn{6}{|c|}{ Treatment site } \\
\hline & \multicolumn{3}{|c|}{ Control } & \multicolumn{3}{|c|}{ Bait station } \\
\hline & $n$ & Mean & SE & $n$ & Mean & SE \\
\hline Trapping & 12 & 3086 & 361 & 7 & 4843 & 505 \\
\hline Controlled shooting & 12 & 2403 & 218 & 6 & 5592 & 489 \\
\hline Drive shooting & 12 & 3390 & 435 & 6 & 4593 & 717 \\
\hline Aerial gunning & 10 & 3273 & 560 & 5 & 5255 & 1,184 \\
\hline No activity & 12 & 3043 & 233 & 7 & 4700 & 478 \\
\hline
\end{tabular}

\section{Discussion}

Techniques for containing emergency disease epidemics within feral swine have only recently been considered in the United States (Lavelle et al., 2011). One requisite for such evaluations is the presence of intense human activity at the population level of feral swine. We believe our culling activities were effective at simulating real-world population level disease control situations. For example, over 4 weeks we deployed 4 commonly used feral swine population control techniques, which were aided by state-of-the art technologies. Throughout the experiment, we were successful in removing 143 feral swine (4.6 feral swine $/ \mathrm{km}^{2}$ ). We believe this removal rate is conservative because we were neither attempting to remove feral swine during the drive shooting phase, nor were we attempting to remove collared animals during the aerial gunning phase. A large proportion of feral swine removals occurred during the aerial gunning phase (87\%) and only $2 \%$ were removed during the trapping phase. These findings support conclusions that aerial gunning is a viable tool for managing emergency disease epidemics in feral swine populations occurring on rangelands (Campbell et al., 2010) and that a pre-baiting period is needed to allow feral swine time to discover bait at trap sites (Saunders and Bryant, 1988; Williams et al., 2011a).

Our visitation rates at the bait station site suggested that it was used heavily, but not exclusively, by feral swine. Visitation by collared peccaries and raccoons was minimal throughout the experiment, whereas visitation rates by white-tailed deer increased steadily with time. We attribute the reduction in bait station visitation by feral swine during the controlled shooting phase to the presence of personnel performing culling activities. These activities were conducted during crepuscular and nocturnal hours when swine normally visited the bait station. Similar human avoidance behavior by feral swine has previously been demonstrated in other regions (Muir and McEwen, 2007). We attribute the reduction in bait station visitation by feral swine during the aerial gunning to the general disturbance and overall reduction in feral swine abundance that occurred during this phase. 
Our prediction that a large proportion of collared feral swine would use the bait station site was not supported by the data. Sixty-two percent of feral swine that were trapped in proximity to the bait station site used it, including one animal that was originally trapped and collared $241 \mathrm{~m}$ away. Similar observations have been made within populations of other ungulates. For example, researchers studying white-tailed deer in West Virginia found from 42 to $62 \%$ of animals used bait sites, depending upon season (Campbell et al., 2006a). Explanations for our relatively low use of the bait station site include the availability of alternative forages (McIlroy et al., 1993), social interactions (Sparklin et al., 2009), or other factors such as initial bait placement not targeting a group of feral swine (Williams et al., 2011a). Future research aimed at increasing the proportion of feral swine using bait stations should consider incorporating multiple bait stations in proximity versus a single large bait station like we deployed and evaluated here.

Similarly, our hypothesis that baiting would cause smaller areas of utilization of feral swine was not directly supported by the data. In fact, means of $95 \%$ and $50 \%$ UDs from the control site and the bait station site were similar during baiting. However, different patterns for UDs areas were evident between the control site and the bait station site. Control site feral swine reduced their UDs over time, whereas bait station site animals reduced their UDs during baiting, followed by expansion after baiting. We believe the presence of the bait station likely explains these observed patterns, as further evidenced by the observation that $88 \%$ of the bait station site feral swine shifted their 50\% UD to include the station during baiting. The presence of the bait station altered the areas of utilization of feral swine and a substantial proportion of their time was spent in proximity. Also, the reduction in the control site utilization distributions over time may be attributed to rising temperatures relegating feral swine to areas near water due to thermoregulatory needs (Baber and Coblentz, 1986).

Our prediction that baiting of feral swine would result in location centroids being closer to the bait station were supported by the data. Furthermore, a trend was evident for bait station site feral swine in which location centroids were closer to the bait station during baiting and culling activities than before and after baiting. These data further illustrate the heavy use of the bait station by these feral swine. Although there are no registered toxicants for use on feral swine in the United States, in many countries toxic baits are socially acceptable and registered for use in emergency disease epidemics and other applications (Cowled et al., 2006a,b; Lapidge et al., in press). Our data demonstrate that while there are major non-target issues with delivering pharmaceuticals to feral swine through baits in the United States (Campbell et al., 2006b; Campbell and Long, 2007, 2009b), 62\% of feral swine in proximity to the bait station used it and could have received a toxic dose or a vaccine dose. This proportion of the population would likely be adequate to lead to disease fadeout and epidemic containment.

Our culling activities resulted in movements outside of former MCP ranges by $48 \%$ of feral swine. However, these movements were short in distance $(\leq 1700 \mathrm{~m})$ and duration ( $\leq 544 \mathrm{~min}$ ) and were conducted by both control site and bait station feral swine. Similar findings have been observed for feral swine pressured with drive hunts in Lower Saxony, Germany (Sodeikat and Pohlmeyer, 2002), trapping and controlled shooting at Fort Benning, Georgia (Sparklin et al., 2009), and aerial gunning in southern Texas (Campbell et al., 2010). Collectively, these studies suggest that common culling activities have only minor impacts on feral swine movements and feral swine are unlikely to disperse and spread pathogens long distances in response to culling activities. Furthermore, feral swine that we studied were healthy and animals of concern in an emergency disease epidemic scenario may be unhealthy and more sedentary. Consequently, the movements we report here are a worst-case scenario.

Counter to our hypothesis, feral swine using the bait station displayed elevated movement rates compared to control site animals. We had predicted that this measure of activity would be less for feral swine using the bait station because their movements would be confined to areas in proximity to the bait station. However, our original bait station placement did not consider the close association between feral swine and sources of free water for physiological needs and thermoregulation (Baber and Coblentz, 1986). We believe that these animals displayed greater daily movements because they regularly travelled to the bait station and sources of free water, which were distant. Alternatively, feral swine using the bait station may have retreated to cover that was distant, resulting in greater movement rates. Contingency planning for emergency disease epidemics should consider the spatial arrangement of critical habitat features, such as free water and cover, when formulating appropriate management activities. It may be appropriate to strategically place bait stations to facilitate movement by feral swine along likely travel routes to enable their removal.

\section{Conclusion}

Based on our observation that only $62 \%$ of feral swine trapped in proximity to the bait station used it, we cannot recommend baiting as an alternative to fences for containing animals during culling activities. However, a high proportion of feral swine that used the bait station shifted their 50\% UD to include the station during baiting, suggesting there is value in using bait stations to establish patterns of feral swine movements, facilitate observation, and improve efficacy when conducting removals. Focal baiting could also be a valuable component of integrated management for controlling feral swine in conjunction with other strategies like culling and fencing. Additionally, practitioners of emergency disease epidemic management can expand culling zones to exceed estimated movement distances and depopulate feral swine below a threshold density, resulting in disease containment (Ward et al., 2007, 2009, 2011; Wobeser, 1994). Lastly, our observations that culling activities, which resulted in severe persecution, did not impact feral swine movements greatly is important in planning for emergency disease epidemics. 


\section{Conflict of interest statement}

The authors declare that they have no conflicts of interest regarding the present study and manuscript.

\section{Acknowledgements}

The study was funded by United States Department of Agriculture (USDA), Animal and Plant Health Inspection Service, Wildlife Services, National Wildlife Research Center. We thank Welder Wildlife Foundation for property access. We thank E. Davis, S. Rabe, and J. Rattan for field assistance. Logistical support was provided by the Caesar Kleberg Wildlife Research Institute at Texas A\&M University-Kingsville and Texas Wildlife Services. The USDA does not recommend endorsement, guarantee nor warrant companies or commercial products mentioned in this study.

\section{References}

Atwill, E.R., Sweitzer, R.A., Pereira, M.C., Gardner, I.A., Van Vuren, D., Boyce, W.M., 1997. Prevalence of and associated risk factors for shedding Cryptosporidium parvum oocysts and Giardia cysts within feral pig populations in California. Appl. Environ. Microb. 63, 3946-3949.

Baber, D.W., Coblentz, B.E., 1986. Density, home range, habitat use, and reproduction in feral pigs on Santa Catalina Island. J. Mammal. 67, 512-525.

Ballesteros, C., Vicente, J., Morriss, G., Jockney, I., Rodríguez, O., Gortázar, C., de la Fuente, J., 2011. Acceptance and palatability for domestic and wildlife hosts of baits designed to deliver a tuberculosis vaccine to wild boar piglets. Prev. Vet. Med. 98, 198-203.

Belden, R.C., Frankenberger, W.B., 1977. A portable root-door hog trap. In: Proceedings of the Southeastern Association of Fish and Wildlife Agencies, vol. 31, pp. 123-125.

Calenge, C., Maillard, D., Fournier, P., Fouque, C., 2004. Efficiency of spreading maize in the garrigues to reduce wild boar (Sus scrofa) damage to Mediterranean vineyards. Eur. J. Wildl. Res. 50, 112-120.

Campbell, T.A., Langdon, C.A., Laseter, B.R., Ford, W.M., Edwards, J.W., Miller, K.V., 2006a. Movements of female white-tailed deer to bait sites in West Virginia USA. Wildl. Res. 33, 1-4.

Campbell, T.A., Lapidge, S.J., Long, D.B., 2006b. Using baits to deliver pharmaceuticals to feral swine in southern Texas. Wildl. Soc. Bull. 34, 1184-1189.

Campbell, T.A., Long, D.B., 2009a. Feral swine damage and damage management in forested ecosystems. For. Ecol. Manage. 257, 2319-2326.

Campbell, T.A., Long, D.B., 2009b. Strawberry-flavored baits for pharmaceutical delivery to feral swine. J. Wildl. Manage. 73, 615-619.

Campbell, T.A., Long, D.B., 2007. Species-specific visitation and removal of baits for delivery of pharmaceuticals to feral swine. J. Wildl. Dis. 43, 485-491.

Campbell, T.A., Long, D.B., Leland, B.R., 2010. Feral swine behavior relative to aerial gunning in southern Texas. J. Wildl. Manage. 74, 337-341.

Campbell, T.A., Long, D.B., Massei, G., 2011. Efficacy of the Boar-Operated System to deliver baits to feral swine. Prev. Vet. Med. 98, 243-249.

Cowled, B.D., Gifford, D.E., Smith, M., Staples, L., Lapidge, S.J., 2006a. Efficacy of manufactured PIGOUT ${ }^{\circledR}$ baits for localized control of feral pigs in the semi-arid Queensland rangelands. Wildl. Res. 33, 427-437.

Cowled, B.D., Lapidge, S.J., Smith, M., Staples, L., 2006b. Attractiveness of a novel omnivore bait PIGOUT $^{\circledR}$, to feral pigs (Sus scrofa) and assessment of risks of bait uptake by non-target species. Wildl. Res. 33, 651-660.

Cushman, J.H., Tierney, T.A., Hinds, J.M., 2004. Variable effects of feral pig disturbances on native and exotic plants in a California grassland. Ecol. Appl. 14, 1746-1756.

Dexter, N., 1996. The effect of an intensive shooting exercise from a helicopter on the behaviour of surviving feral pigs. Wildl. Res. 23, 435-441.

Ditchkoff, S.S., West, B.C., 2007. Ecology and management of feral hogs. Human Wildl. Confl. 1, 149-151.

Hall, J.S., Minnis, R.B., Campbell, T.A., Barras, S., DeYoung, R.W., Palilonia, K., Avery, M.L., Sullivan, H., Clark, L., McLean, R.G., 2008. Influenza exposure in feral swine from the United States. J. Wildl. Dis. 44, 362-368.

Hanson, R.P., Karstad, L., 1959. Feral swine in the southeastern United States. J. Wildl. Manage. 23, 64-74.
Hone, J., Pech, R., 1990. Disease surveillance in wildlife with emphasis on detecting foot and mouth disease in feral pigs. J. Environ. Manage. 31, 173-184.

Hooge, P.N., Eichenlaub, B., 1997. Animal Movement Extension to ArcView. Version 1.1. U.S. Geological Survey, Anchorage, AK, USA.

Jay, M.T., Cooley, M., Carychao, D., Wiscomb, G.W., Sweitzer, R.A. Crawford-Miksza, L., Farrar, J.A., Lau, D.K., O'Connell, J., Millington, A., Asmundson, R.V., Atwill, E.R., Mandrell, R.E., 2007. Escherichia coli 0157:H7 in feral swine near spinach fields and cattle, central California coast. Emerg. Infect. Dis. 13, 1908-1911.

Kaller, M.D., Kelso, W.E., 2006. Swine activity alters invertebrate and microbial communities in a Coastal Plain watershed. Am. Midl. Nat. $156,163-177$.

Kreeger, T.J., Arnemo, J.M., Raath, J.P., 2002. Handbook of Wildlife Chemical Immobilization. International Edition. Wildlife Pharmaceuticals, Fort Collins, CO, USA.

Lapidge, S., Wishart, J., Staples, L., Fagerstone, K., Campbell, T., Eisemann, J. Development of a feral swine toxic bait (HOG-GONE ${ }^{\circledR}$ ) and bait hopper $\left(\right.$ HOGHOPPER $^{\mathrm{TM}}$ ) in Australia and the USA. Proc. Wildl. Dam. Manage. Conf. 14 , in press.

Lavelle, M.J., VerCauteren, K.C., Hefley, T.J., Phillips, G.E., Hygnstrom, S.E., Long, D.B., Fischer, J.W., Swafford, S.R., Campbell, T.A., 2011. Evaluation of fences for containing feral swine under simulated depopulation conditions. J. Wildl. Manage. 75, 1200-1208.

Littell, R.C., Milliken, G.A., Stroup, W.W., Wolfinger, R.D., Schabenberger, O., 2006. SAS for Mixed Models, 2nd edition. SAS Press, Cary, North Carolina, USA.

Lloyd-Smith, J.O., Cross, P.C., Briggs, C.J., Daugherty, M., Getz, W.M., Latto, J., Sanchez, M.S., Smith, A.B., Swei, A., 2005. Should we expect population thresholds for wildlife disease? Trends Ecol. Evol. 20, 511-519.

Matschke, G.H., 1962. Trapping and handling European wild hogs. In: Proceedings of the Southeastern Association of Fish and Wildlife Agencies, vol. 16, pp. 21-24.

McCann, B.E., Garcelon, D.K., 2008. Eradication of feral pigs from Pinnacles National Monument. J. Wildl. Manage. 72, 1287-1295.

McIlroy, J.C., Gifford, E.J., 1997. The 'Judas' pig technique: a method that could enhance control programmes against feral pigs Sus scrofa. Wildl. Res. 24, 483-491.

McIlroy, J.C., Gifford, E.J., Forrester, R.I., 1993. Seasonal patterns in bait consumption by feral pigs (Sus scrofa) in the Hill Country of southeastern Australia. Wildl. Res. 20,637-651.

Meng, X.J., Lindsay, D.S., Sriranganathan, N., 2009. Wild boars as sources for infectious disease in livestock and humans. Philos. Trans. R. Soc. B 364, 2697-2707.

Mohr, C.O., 1947. Table of equivalent populations of North American small mammals. Am. Midl. Nat. 37, 223-249.

Muir, T.J., McEwen, G.,2007. Methods and strategies for managing feral hog damage in grain production areas in central Texas. In: Managing Vertebrate Invasive Species: Proceedings of an International Symposium, USDA/APHIS/WS. National Wildlife Research Center, Fort Collins, CO, USA, pp. 445-450.

Reidy, M.M., Campbell, T.A., Hewitt, D.G., 2008. Evaluation of electric fencing to inhibit feral pig movements. J. Wildl. Manage. 72, $1012-1018$

Reidy, M.M., Campbell, T.A., Hewitt, D.G., 2011. A mark-recapture technique for monitoring feral swine populations. Range Ecol. Manage. 64, 316-318.

Rossi, S., Pol, F., Forot, B., Maeew-provin, N., Rigaux, S., Bronner, A., Le Potier, M.-F., 2010. Preventive vaccination contributes to control classical swine fever in wild boar (Sus scrofa sp.). Vet. Microbiol. 142, 99-107.

Saunders, G., Bryant, H., 1988. The evaluation of a feral pig eradication program during a simulated exotic disease outbreak. Aust. Wildl. Res. $15,73-81$.

Seward, N.W., VerCauteren, K.C., Witmer, W.G., Engeman, R.M., 2004. Feral swine impacts on agricultural and the environment. Sheep Goat Res. J. 19, 24-40.

Silverman, B.W., 1986. Density Estimation for Statistics and Data Analysis. Chapman Hall, London, United Kingdom.

Sodeikat, G., Pohlmeyer, H.K., 2002. Temporary home range modifications of wild boar family groups (Sus scrofa L.) caused by drive hunts in Lower Saxony (Germany). Z. Jadwiss. Suppl. 48, 161-166.

Sparklin, B.D., Mitchell, M.S., Hanson, L.B., Jolley, D.B., Ditchkoff, S.S., 2009. Territoriality of feral pigs in a highly persecuted population on Fort Benning, Georgia. J. Wildl. Manage. 73, 497-502.

Ward, M.P., Highfield, L.D., Laffan, S.W., 2011. Disease spread models in wild and feral animal populations: application of artificial life models. OIE Sci. Technol. Rev. 30, 437-446. 
Ward, M.P., Laffan, S.W., Highfield, L.D., 2007. The potential role of wild and feral animals as reservoirs of foot-and-mouth disease. Prev. Vet. Med. 80, 9-23.

Ward, M.P., Laffan, S.W., Highfield, L.D., 2009. Modelling spread of footand-mouth disease in wild white-tailed deer and feral pig populations using a geographic-automata model and animal distributions. Prev. Vet. Med. 91, 55-63.

Williams, B.L., Holtfreter, R.W., Ditchkoff, S.S., Grand, J.B., 2011a. Efficacy of time-lapse intervals and simple baits for camera surveys of wild pigs. J. Wildl. Manage. 75, 655-659.

Williams, B.L., Holtfreter, R.W., Ditchkoff, S.S., Grand, J.B., 2011b. Trap style influences wild pig behavior and trapping success. J. Wildl. Manage. $75,432-436$.
Williams, E.S., Barker, I.K., 2001. Infectious Diseases of Wild Mammals. Iowa State University Press, Ames, IA, USA.

Wobeser, G.A., 1994. Investigation and Management of Diseases in Wild Animals. Plenum Press, New York, NY, USA.

Worton, B.J., 1989. Kernel methods for estimating the utilization distribution in home-range studies. Ecology 70, 164-168.

Welder Wildlife Foundation [WWF], 2009. The Rob and Bessie Welder Wildlife Foundation biennial report, 2006-2008. http:// welderwildlife.org/fileadmin/user/PDF_s/2007_WWF_Biennial_ Report.pdf (accessed 13.12.11).

Wyckoff, A.C., Henke, S.E., Campbell, T.A., Hewitt, D.G., VerCauteren, K.C., 2009. Feral swine contact with domestic swine: a serologic survey and assessment of potential for disease transmission. J. Wildl. Dis. 45, 422-429. 